\title{
Study on High School Teachers' Self-Esteem in Decision Making and Decision Making Styles
}

\section{Yaşar ÇORUH ${ }^{1}$ Mustafa VURAL ${ }^{2}$}

A Agrríbrahim Çecen University, School of Physical Education and Sports, A $\breve{g} r$, Turkey. Email:yasar_coruh@hotmail.com Tel: +905323928411

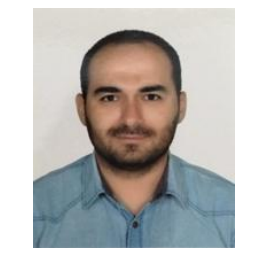

( Corresponding Author)

\begin{abstract}
This research was carried out in order to investigate self-esteem of high school teachers in Erzurum while making decision and their decision making styles in terms of some variables. In the research, descriptive survey method which aimed to reveal current situation, was used. A total of 160 teachers -of whom 37 are female and 123 are male- working in high schools in Erzurum in 2018-2019 spring semester, participated in the research. In the research, "Melbourne Decision Making Questionnaire" developed by Mann et al. (1998) and adapted to Turkish by Deniz (2004) and "Personal Information Form" developed by researchers were used as data collection tool. Independent Samples T-Test was used in paired comparisons and one-way Anova test was used in multiple comparisons. In multiple comparisons, Tukey-test was used in order to determine between which groups difference existed. Margin of error was considered as 0.05 in this study. As a result of the research, when demographic variables were examined, it was seen that postponer decision making style which is sub-dimension of scale of self-esteem in decision making and decision making styles differentiated according to gender variable of the participants. It was seen that carefully decision making dimension which is sub-dimension of decision making styles scale differentiated significantly according to administrative function variable; and also in age variable, avoidant decision making and panic decision making sub-dimensions which are sub-dimensions of decision making styles scale differentiated significantly. In professional seniority variable, it was determined that avoidant decision making sub-dimension which is sub-dimension of decision making styles scale differentiated significantly.
\end{abstract}

Keywords: Decision making, Decision making styles, Self-confidence, Education, Self-esteem, Education.

Citation | Yaşar ÇORUH; Mustafa VURAL (2019). Study on High School Teachers' Self-Esteem in Decision Making and Decision Making Styles. Asian Journal of Education and Training, 6(2): 362 Masin 368.

History:

Received: 14 February 2019

Revised: 28 March 2019

Accepted: 2 May 2019

Published: 24 July 2019

Licensed: This work is licensed under a Creative Commons

Attribution 3.0 License (c) $\mathbf{E}$

Publisher: Asian Online Journal Publishing Group
Acknowledgement: Both authors contributed to the conception and design of the study.

Funding: This study received no specific financial support.

Competing Interests: The authors declare that they have no conflict of interests.

Transparency: The authors confirm that the manuscript is an honest, accurate, and transparent account of the study was reported; that no vital features of the study have been omitted; and that any discrepancies from the study as planned have been explained.

Ethical: This study follows all ethical practices during writing.

\section{Contents}

1. Introduction ...n.

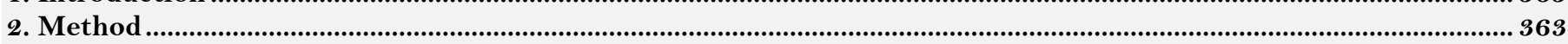

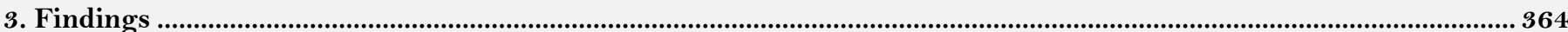

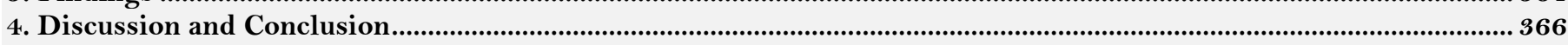

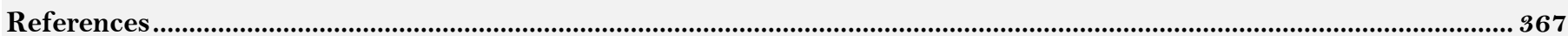




\section{Contribution of this paper to the literature}

This study contributes to existing literature by investigating self-esteem of high school teachers in

Erzurum while making decision and their decision making styles in terms of some variables.

\section{Introduction}

People have to make decisions continually during time from birth to death. Humans who start to perceive their environment create their knowledge and judgments in line with their perceptions, shape their mental patterns that they will use to regulate future behaviors, give direction to the knowledge that they will use in line with environmental changes and developments. Human is a social being who lives in a certain group and makes decisions in almost every stage of his/her life since he/she is not a being who automatically adapts himself/herself to the environment with instinctive reactions (Koçel, 2001). Importance degree of decisions that are made emerges as a result of changes and developments showed by individual in future periods. These decisions vary according to environmental factors and characteristics of situations that have to be decided. Decision is selecting the most appropriate possibility for achieving a goal and the most appropriate one of various action situations that may occur in existing conditions. Decision making is a process of selection and choice as a result of cognitive and behavioral efforts (Kuzgun, 1992).

The most commonly used definition of decision making in the literature is the process of choosing one of the various ways that is thought to enable an individual to reach the goal he/she tries to achieve (Kuzgun, 1992). Decision making which is a learned behavior during developmental periods, is exhibited by going through phases such as recognizing the situation that needs to be decided and defining the situation, determining options by collecting information about the situation, reviewing and evaluating options, choosing and implementing the option that will cause the most positive and effective results for individual's life, choosing again by evaluating results if necessary and getting feedback from social environment about the choice made (Marco et al., 2003).Decision making is known as a stressful process because it is a difficult task. It is a difficult process to look for alternatives, to investigate and find them and to compare harms and benefits of each of them (Eren, 2003). Different characteristics of people affect their decision making behaviors. Situations that are complex and that have many choices, make decision making difficult. This process can become a stress factor for the individual. At the same time, this decision complexity affects decision making situation of an individual negatively (Shiloh et al., 2001). From this point of view, self-confident individuals are more successful while making decisions and are more successful in dealing with this situation. Individuals with high level of self-esteem are generally self-confident, willing to succeed, optimistic, undeterred, open to new ideas and experiences and researcher, relaxed and compassionate in human relations, responsible and entrepreneur (Mağden and Küçük, 1993). In other words, it is thought that individuals with high self-esteem are successful in making decisions and evaluating the results of their decisions and do not live to regret. From this point of view, when it is thought that decision making is a fundamental step in the process of making plans for the future and shaping the lives of individuals, it is important for high school students. From this point of view, schools are organizations that form important cornerstones of education systems. All of the studies conducted related to education are generally made to improve quality of the education in schools and to improve the existing system. In schools where education is organized, high schools are in an important position and are among the cornerstones of the steps taken for making dreams of students related to university where their future goals are shaped come true. It is teachers' and school personnel's job to increase quality of education in schools. In this process, guiding students in schools in the best way, providing guidance for students in the future periods represent a valuable process for teachers. It is an inevitable situation where teachers enter decision making process while carrying out this whole process. Opinion of controlling this situation efficiently and realizing it successfully fall to also teachers' share. It was seen that teachers also got involved in the decision process from the point of students in decision process and it was tried to reveal which self-esteem and decision making styles were used by teachers while making decision in terms of some demographic variables.

\section{Method}

\subsection{Research Model}

In the research, screening model which aims to describe attitudes, tendencies and opinions numerically or quantitatively by performing studies on a sample group chosen from a population, has been used (Creswell, 2013). This method can be identified as describing a situation in the past or present as it is. What is important in this method is to be able to define an event, individual or object as it is in its conditions and to observe it without changing the current situation (Karasar, 2012). In the research, survey technique which is frequently utilized in screening studies, has been used as data collection technique (Erkuş, 2013).

\subsection{Population and Sample}

Population of the study consists of teachers working in high schools continuing educational activities in Erzurum. Sample group of the research was determined by filling scales randomly while they were continuing their duties during spring term of 2018-2019 academic year. Sample group of the research consists of a total of 160 voluntary teachers, of whom 123 are male and 37 are female.

\subsection{Data Collection Tools}

\section{- Melbourne Decision Making Questionnaire (MDMQ I-II)}

It was developed by Mann et al. (1998) (Melbourne Decision Making Questionnaire) to compare self-esteem and decision making styles of university students while making decision in an intercultural research involving six countries. It is a scale consisting of two parts. This scale was adapted to Turkish by Deniz (2004) in order to determine decision making styles of Turkish university students and to make comparative studies with other country students (Deniz, 2004). Melbourne Decision Making Questionnaire consists of two parts. 
First Part: It aims to determine self-esteem (self-confidence) in decision making. It consists of 6 articles and one sub-factor.

Second Part is a scale consisting of 22 articles and four sub-factors aiming to determine decision-making styles. These are; 1.Carefully Decision Making Style: It is an individual's situation of searching for necessary information carefully before making a decision and making choice after evaluating alternatives carefully. 2.Avoidant Decision Making Style: It is an individual's situation of avoiding making decisions, tending to leave decisions to others and trying to avoid making decisions by transferring responsibility to another person. 3. Postponer Decision Making Style: It is an individual's situation of postponing, delaying and procrastinating the decision continuously without a valid reason. 4. Panic Decision Making Style: It is an individual's situation of trying to reach solution quickly and impatiently by feeling under the pressure of time when he/she is faced with a decision situation (Deniz, 2004).

Both parts consist of 3 point likert type (True, Slightly True, Not True) answering options. Validity and reliability studies of Melbourne Decision Making Questionnaire I-II (MDMQ) were conducted on second-year students of Computer Systems Teaching and Automotive Teaching Departments of Faculty of Technical Education in Selçuk University in 2002-2003 academic year and data were collected from 154 students (Deniz, 2004).

\subsection{Data Analysis}

SPSS 23.00 package program was used to analyze data. Normality of data was tested and it was determined that data distributed normally. Independent Samples T-Test was used in paired comparisons and one-way Anova test was used in multiple comparisons. In multiple comparisons, Tukey-test was used in order to determine between which groups difference existed. Margin of error was considered as 0.05 in this study.

\section{Findings}

Percentage and frequency values of the participants' demographic characteristics and findings of self-esteem and decision making styles scale were used.

Table-1. Percentage and Frequency Table Related to Research Participants.

\begin{tabular}{c|c|c}
\hline Gender & Frequency & Percentage \\
\hline Male & 123 & 76,9 \\
\hline Female & 37 & 100.0 \\
\hline Total & 160 & Percentage \\
\hline Administrative Function & Frequency & 15,0 \\
\hline Yes & 24 & 85,0 \\
\hline No & 136 & 100,0 \\
\hline Total & 160 & Percentage \\
\hline Professional Seniority & Frequency & 38,8 \\
\hline $1-5$ years & 62 & 21,2 \\
\hline $6-10$ years & 64 & 100,0 \\
\hline 11 years and more & 34 & Percentage \\
\hline Total & 160 & 23,8 \\
\hline Age & Frequency & 46,9 \\
\hline 30 years and younger & 38 & 13,1 \\
\hline $31-35$ years & 75 & 16,2 \\
\hline $36-40$ years & 21 & 100,0 \\
\hline 41 years and older & 26 & \\
\hline Total & 160 & \\
\hline
\end{tabular}

When Table 1 is examined, it is seen that $76.9 \%$ of the participants are male, $23.1 \%$ are female teachers, $15 \%$ have administrative function and $85 \%$ do not have administrative function. When seniority is considered, rate of those who have professional seniority between 1-5 years is $38,8 \%$, rate of those who have seniority between 6-10 years is $40 \%$ and rate of teachers who have 11 years of seniority or more is $21,2 \%$. When ages of the participants are examined, it is seen that rate of those in age group 30 and younger is $23,8 \%$, rate of those in age group $31-35$ is $46,9 \%$, rate of those in age group $36-40$ is $13,1 \%$ and rate of those in age group 41 and older is $16,2 \%$.

Table-2. Results of t-test showing comparison of sub-dimension scores of participants' scale of self-esteem in decision making and decision making styles in terms of gender.

\begin{tabular}{|c|c|c|c|c|c|c|}
\hline Decision-making Styles Scale & Gender & $\mathbf{N}$ & Mean & Standard deviation & $\mathbf{T}$ & $\mathbf{P}$ \\
\hline \multirow{2}{*}{ Self-esteem in decision making } & Male & 123 & 2,0136 & ,20199 & \multirow[b]{2}{*}{$-2,714$} & \multirow{2}{*}{, $007^{*}$} \\
\hline & Female & 37 & 2,1216 &, 24422 & & \\
\hline \multirow{2}{*}{ Carefully decision making } & Male & 123 & 1,2940 & ,32579 & \multirow{2}{*}{478} & \multirow{2}{*}{,633 } \\
\hline & Female & 37 & 1,2658 &, 27627 & & \\
\hline \multirow{2}{*}{ Avoidant decision making } & Male & 123 & 2,4268 &, 41497 & \multirow{2}{*}{-1.121} & \multirow{2}{*}{, 264} \\
\hline & Female & 37 & 2,5090 & ,29644 & & \\
\hline \multirow{2}{*}{ Postponer decision making } & Male & 123 & 2,2992 & ,40681 & \multirow{2}{*}{-2.551} & \multirow{2}{*}{, $012^{*}$} \\
\hline & Female & 37 & 2,4865 & ,33513 & & \\
\hline \multirow{2}{*}{ Panic decision making } & Male & 123 & 2,3642 & ,39425 & \multirow{2}{*}{,- 261} & \multirow{2}{*}{, 795} \\
\hline & Female & 37 & 2.3838 & ,42000 & & \\
\hline
\end{tabular}
$\mathrm{P}=0,05$.

When Table 2 is examined, it is seen that postponer decision making dimension which is sub-dimension of scale of self-esteem in decision making and decision making styles differentiates significantly according to gender variable of the participants $(\mathrm{p}<0.05)$; other sub-dimensions of the decision making scale do not differentiate 
significantly according to gender ( $\mathrm{p}>0.05)$. It is seen that difference in self-esteem in decision making and postponer decision making sub-dimension is found to be high in favor of women.

Table-3. Results of t-test showing comparison of sub-dimension scores of participants' scale of self-esteem in decision making and decision making styles in terms of having administrative function.

\begin{tabular}{|c|c|c|c|c|c|c|}
\hline Decision-making Styles Scale & $\begin{array}{c}\text { Administrative } \\
\text { Function }\end{array}$ & $\mathbf{N}$ & Mean & Standard deviation & $\mathbf{T}$ & $\mathbf{P}$ \\
\hline \multirow{2}{*}{ Self-esteem in decision making } & Yes & 24 & 2,0903 &, 21411 & \multirow{2}{*}{1.272} & \multirow{2}{*}{,205 } \\
\hline & No & 136 & 2,0294 & ,21648 & & \\
\hline \multirow{2}{*}{ Carefully decision making } & Yes & 24 & 1,4236 & ,33326 & \multirow{2}{*}{2.332} & \multirow{2}{*}{, $021 *$} \\
\hline & No & 136 & 1,2635 & ,30601 & & \\
\hline \multirow{2}{*}{ Avoidant decision making } & Yes & 24 & 2,3889 &, 37644 & \multirow{2}{*}{,- 772} & \multirow{2}{*}{, 441} \\
\hline & No & 136 & 2,4559 & ,39453 & & \\
\hline \multirow{2}{*}{ Postponer decision making } & Yes & 24 & 2,2417 & ,35864 & \multirow{2}{*}{-1.348} & \multirow{2}{*}{, 179} \\
\hline & No & 136 & 2,3603 & ,40355 & & \\
\hline \multirow{2}{*}{ Panic decision making } & Yes & 24 & 2,3417 & ,27333 & \multirow{2}{*}{,- 360} & \multirow{2}{*}{, 720} \\
\hline & No & 136 & 2,3735 &, 41797 & & \\
\hline
\end{tabular}

$\overline{\mathrm{P}=0,05 \text {. }}$

When Table 3 is examined, it is seen that avoidant, panic and postponer decision making dimensions which are sub-dimensions of scale of self-esteem in decision making and decision making styles do not differentiate significantly according to participants' variable of having administrative function ( $p>0.05)$. It is also seen that carefully decision making dimension which is sub-dimension of scale of decision making styles differentiates significantly $(\mathrm{p}<0.05)$. It is seen that participants who have administrative function have higher scores in using carefully decision making styles than those who do not have administrative function.

Table-4. Results of one-way Anova test showing comparison of sub-dimension scores of participants's scale of self-esteem in decision making and decision making styles in terms of age.

\begin{tabular}{|c|c|c|c|c|c|c|c|}
\hline $\begin{array}{l}\text { Decision-making Styles } \\
\text { Scale }\end{array}$ & Age & $\mathbf{N}$ & Mean & $\begin{array}{l}\text { Standard } \\
\text { deviation }\end{array}$ & $\mathbf{F}$ & $\mathbf{P}$ & $\begin{array}{l}\text { Significant } \\
\text { difference }\end{array}$ \\
\hline \multirow{4}{*}{$\begin{array}{l}\text { Self-esteem in decision } \\
\text { making }\end{array}$} & 30 years and younger & 38 & 1,9912 &, 19738 & \multirow{4}{*}{2.238} & \multirow{4}{*}{0.086} & \\
\hline & $31-35$ years & 75 & 2,0267 &, 21407 & & & \\
\hline & $36-40$ years & 21 & 2,1349 &, 22742 & & & \\
\hline & 41 years and older & 26 & 2,0641 &, 22646 & & & \\
\hline \multirow{4}{*}{ Carefully decision making } & 30 years and younger & 38 & 1,3465 & ,36839 & \multirow{4}{*}{2.587} & \multirow{4}{*}{0,055} & \\
\hline & $31-35$ years & 75 & 1,2156 &, 24777 & & & \\
\hline & $36-40$ years & 21 & 1,3730 &, 33294 & & & \\
\hline & 41 years and older & 26 & 1,3397 &, 35740 & & & \\
\hline \multirow{4}{*}{ Avoidant decision making } & 30 years and younger & 38 & 2,5570 & ,33842 & \multirow{4}{*}{3,074} & \multirow{4}{*}{$0,029 *$} & \multirow{4}{*}{ A-D } \\
\hline & $31-35$ years & 75 & 2,4444 & ,40486 & & & \\
\hline & $36-40$ years & 21 & 2,4762 &, 34675 & & & \\
\hline & 41 years and older & 26 & 2,2628 &, 41143 & & & \\
\hline \multirow{4}{*}{$\begin{array}{l}\text { Postponer decision } \\
\text { making }\end{array}$} & 30 years and younger & 38 & 2,3895 & ,40523 & \multirow{4}{*}{0,410} & \multirow{4}{*}{0,746} & \\
\hline & $31-35$ years & 75 & 2,3440 &, 37425 & & & \\
\hline & $36-40$ years & 21 & 2,3333 & ,33066 & & & \\
\hline & 41 years and older & 26 & 2,2769 &, 50621 & & & \\
\hline \multirow{4}{*}{ Panic decision making } & 30 years and younger & 38 & 2,5684 & ,30678 & \multirow{4}{*}{4,713} & \multirow{4}{*}{$0,004^{*}$} & \multirow{4}{*}{$\begin{array}{l}\mathrm{A}-\mathrm{B}, \mathrm{C} \\
\text { and D }\end{array}$} \\
\hline & $31-35$ years & 75 & 2,3307 &, 36241 & & & \\
\hline & 36-40 years & 21 & 2,2571 &, 51437 & & & \\
\hline & 41 years and older & 26 & 2,2769 &, 43479 & & & \\
\hline
\end{tabular}

$\mathrm{P}=0,05 \quad \mathrm{~A}=30$ years and younger $\mathrm{B}=31-35$ years $\mathrm{C}=36-40$ years $\mathrm{D}=4.1$ years and older.

When Table 4 is examined, it is seen that carefully decision making, postponer decision making subdimensions which are sub-dimensions of scale of self-esteem in decision making and decision making styles do not differentiate significantly according to age variable of the participants ( $p>0.05)$. It is also seen that avoidant decision making and panic decision making sub-dimensions which are sub-dimensions of scale of decision making styles differentiate significantly $(\mathrm{p}<0.05)$. According to this, it is seen that participants in age group 30 and younger use avoidant decision making styles more than participants in age group 41 and older and also participants in age group 30 and younger use panic decision making styles more than other participants.

When Table 5 is examined, it is seen that carefully decision making, postponer decision making and panic decision making sub-dimensions which are sub-dimensions of scale of self-esteem in decision making and decision making styles do not differentiate significantly according to professional seniority variable of the participants $(p>0.05)$. It is also seen that avoidant decision making sub-dimension which is sub-dimensions of scale of decision making styles differentiates significantly $(\mathrm{p}<0.05)$. According to this, it is seen that participants who have $1-5$ years of professional seniority use avoidant decision making styles more than participants who have 11 years of professional seniority and more. 
Table-5.Results of one-way Anova test showing comparison of sub-dimension scores of participants' scale of self-esteem in decision making and decision making styles in terms of professional seniority.

\begin{tabular}{|c|c|c|c|c|c|c|c|}
\hline Decision-making Styles Scale & $\begin{array}{c}\text { Professional } \\
\text { Seniority } \\
\end{array}$ & $\mathbf{N}$ & Mean & $\begin{array}{l}\text { Standard } \\
\text { deviation }\end{array}$ & $\mathbf{F}$ & $\mathbf{P}$ & $\begin{array}{c}\text { Significant } \\
\text { difference }\end{array}$ \\
\hline \multirow{3}{*}{ Self-esteem in decision making } & $1-5$ years & 62 & 2,0188 & ,20491 & \multirow{3}{*}{1,412} & \multirow{3}{*}{, 247} & \\
\hline & $6-10$ years & 64 & 2,0286 & ,21934 & & & \\
\hline & 11 and more & 34 & 2,0931 & ,22915 & & & \\
\hline \multirow{3}{*}{ Carefully decision making } & $1-5$ years & 62 & 1,2688 & ,27881 & \multirow{3}{*}{1,603} & \multirow{3}{*}{,205 } & \\
\hline & $6-10$ years & 64 & 1,2604 & ,32648 & & & \\
\hline & 11 and more & 34 & 1,3725 & ,34587 & & & \\
\hline \multirow{3}{*}{ Avoidant decision making } & $1-5$ years & 62 & 2,5484 & ,30833 & \multirow{3}{*}{4.994} & \multirow{3}{*}{$\begin{array}{c}\text {,008 } \\
*\end{array}$} & \multirow{3}{*}{ A-C } \\
\hline & $6-10$ years & 64 & 2,4271 &, 40703 & & & \\
\hline & 11 and more & 34 & 2,2941 & ,44958 & & & \\
\hline \multirow{3}{*}{ Postponer decision making } & $1-5$ years & 62 & 2,3548 & ,36650 & \multirow{3}{*}{,068 } & \multirow{3}{*}{,934 } & \\
\hline & $6-10$ years & 64 & 2,3406 &, 40580 & & & \\
\hline & 11 and more & 34 & 2,3235 &, 44861 & & & \\
\hline \multirow{3}{*}{ Panic decision making } & $1-5$ years & 62 & 2,4516 & ,37274 & \multirow{3}{*}{2,673} & \multirow{3}{*}{,072 } & \\
\hline & $6-10$ years & 64 & 2,3437 & ,38292 & & & \\
\hline & 11 and more & 34 & 2,2647 & , 45319 & & & \\
\hline
\end{tabular}

$\mathrm{P}=\mathbf{0 , 0 5}=\mathrm{A}=1-5$ years $\mathrm{B}=6-10$ years $\mathrm{C}=11$ years and more

\section{Discussion and Conclusion}

In the study carried out in order to determine self-esteem in decision making and decision-making styles of physical education teachers working in high schools according to some demographic variables, following conclusions were obtained:

When percentage frequency values of the participants are examined, it is seen that $76.9 \%$ of the participants are male, $23.1 \%$ are female teachers, $15 \%$ have administrative function and $85 \%$ do not have administrative function. When seniority is considered, rate of those who have professional seniority between $1-5$ years is $38,8 \%$, rate of those who have seniority between $6-10$ years is $40 \%$ and rate of teachers who have 11 years of seniority or more is $21,2 \%$. When ages of the participants are examined, it is determined that rate of those in age group 30 and younger is $23,8 \%$, rate of those in age group $31-35$ is $46,9 \%$, rate of those in age group $36-40$ is $13,1 \%$ and rate of those in age group 41 and older is $16,2 \%$.

When results related to demographic variables of the study are examined, it is concluded that postponer decision making dimension which is sub-dimension of scale of self-esteem in decision making and decision making styles differentiates significantly according to gender variable of the participants and other sub-dimensions of the decision making scale do not differentiate significantly according to gender. It is seen that difference in self-esteem in decision making and postponer decision making sub-dimension is found to be high in favor of women. In other words, it is possible to say that female participants use self-esteem in decision making and postponer decision making style more. In other words, women respect themselves more in their decisions and it is understood from the research results that they show a postponing attitude while making these decisions Table 2 . When relevant literature is examined, there are many studies determining level of using decision making styles according to gender variable. In a study conducted by Temur (2012) it was revealed that there were no significant differences in the other sub-dimensions except for averages of avoidant decision making scores in the examination of subdimensions of decision making styles according to gender variable. In a study conducted in Netherlands, Tuinstra et al. (2000) found that self-confidence in decision making was higher in favor of males and sub-dimensions of panic decision making, avoidant decision making and making decision without thinking were higher in favor of females.

There are also studies that can't find significant difference in self-esteem in decision making and decision making styles according to gender variable. Among these, Vural (2013) determined that self-esteem in decision making and decision making styles did not differ significantly in terms of gender as a result of study that he conducted on employees working at provincial directorate of youth services and sports. It is thought that these differences result from working groups and cultural differences. In any case, Mau (2000), Mann et al. (1998) who conducted studies on this subject, have shown that intercultural differences are an important element in decision making.

It is determined that avoidant, panic and postponer decision making dimensions which are sub-dimensions of scale of self-esteem in decision making and decision making styles do not differentiate significantly according to participants' variable of having administrative function. It is also seen that carefully decision making dimension which is sub-dimension of scale of decision making styles differentiates significantly. It is concluded that participants who have administrative function use carefully decision making styles at a higher level than those who do not have administrative function Table 3 . It is possible to explain this as follows; those who have administrative function are more careful while carrying out their duties and making decisions related to the future. In his study that he conducted on primary and secondary school teachers, Ercan (2014) revealed that decision making skills did not differentiate according to the type of performing duty. However, when he examined averages of the scores, he found that participants who were in the position of principal had higher scores in decision making skills such as perception, identification and solution suggestions than vice principals. Vural (2016) revealed similar results with our results in his study conducted on employees working at provincial directorate of youth services and sports. As a result of the study, he determined that participants who had administrative function used carefully decision making styles at a higher level than those who did not have administrative function. In other words, it is possible to say that those who have administrative function are more careful and consider alternative situations while making decisions. 
It is concluded that carefully decision making, postponer decision making sub-dimensions which are subdimensions of scale of self-esteem in decision making and decision making styles do not differentiate significantly according to age variable of participant teachers and avoidant decision making and panic decision making subdimensions differentiate significantly Table 4. According to this, it is seen that participants in age group 30 and younger use avoidant decision making styles more than participants in age group 41 and older and also participants in age group 30 and younger use panic decision making styles more than other participants. It is seen in the relevant literature that there are studies that find self-esteem in decision making and decision making styles significant according to age variable. Among these, Ölçüm (2015) found that there were significant differences in instant decision making, dependent decision making and rational decision making styles according to ages in the study conducted on school administrators. Ilmez (2010) found directors' avoidance decision making styles perceptions high in the study conducted on directors and employees of air forces command and emphasized that age affected avoidance decision making style. Again, Baron et al. (1993) and Temur (2012) found that participants' decision making styles were significantly different according to age variable.

There are also studies that found that self-esteem in decision making and decision making styles did not differ according to age. Çorapçı (2015) determined in the study conducted on classroom teachers that self-esteem in decision making and decision making styles did not differ significantly according to age variable. In the study conducted to examine decision making styles of school administrators, Kurban (2015) determined that subdimensions of decision making styles did not differ significantly according to age. In another study conducted related to employees of sports federation, Vural (2016) determined that self-esteem in decision making and decision making styles did not differ according to age variable. It is thought that all these differences result from diversity of working groups or institutions.

It is concluded that participant teachers' carefully decision making, postponer decision making and panic decision making sub-dimensions which are sub-dimensions of scale of self-esteem in decision making and decision making styles do not differentiate significantly according to professional seniority variable and avoidant decision making sub-dimension differentiates significantly Table 5 . According to this, it is seen that participants who have 1-5 years of professional seniority use avoidant decision making styles more than participants who have 11 years of professional seniority and more. When relevant literature was examined, in his study conducted related to teachers, Temur (2012) revealed from studies conducted that postponer and panic decision making styles that were decisionmaking styles sub-dimensions did not differentiate significantly according to seniority variable of teachers; however, their carefully and avoidant decision making styles differentiated significantly. Again, in a study conducted according to seniority variable, Ölçüm (2015) revealed that there were significant differences between professional seniority of school administrators and teachers and decision making styles of them apart from intuitional decision making style.

When studies are examined according to professional seniority year or period variables, Üngüren (2011) revealed in his study conducted on department managers in hotel businesses that there was a significant difference in intuitional, avoidant and spontaneous decision making styles according to managers' professional working time. When literature researches are examined, it is thought that differences result from working groups when selfesteem in decision making and decision making styles are examined.

Consequently, it is determined in the research that teachers' self-esteem in decision making and decision making styles differentiate according to demographic variables.

\section{References}

Baron, J., L. Granato, M. Spranca and E. Teubal, 1993. Exploration study of youth early from bias decision making in children. MerrillPalmer Quarterly, 39: 23-47.

Çorapçı, A., 2015. Determining classroom teachers' decision making styles and job satisfaction Master Thesis. Karamanoğlu Mehmet Bey University Institute of Social Sciences.

Creswell, J.W., 2013. Research design: Qualitative, quantitative and mixed approaches. (Translated by Selçuk Beşir Demir). Ankara: Educating Book.

Deniz, M.E., 2004. A research on investigation of the relationship between self-esteem decision making styles and problem solving skills of university students in decision making. Journal of Educational Research, 15: 23-35.

Ercan, G., 2014. Baca selengkapnya investigation of relationship between personality characteristics and decision making skills of secondary school administrators. Master Thesis. Okan University Institute of Social Sciences.

Eren, E., 2003. Management and organization (contemporary and global approaches). Istanbul: Beta Printing and Publishing.

Erkuş, A., 2013. Scientific research process for behavioral sciences. Ankara: Seçkin Publication.

Ilmez, M., 2010. Determining the relationship between leadership styles and decision making styles of executives and employees in a public institution. Master's Thesis. Ufuk University Institute of Social Sciences.

Karasar, N., 2012. Scientific research method. Ankara: Nobel Academic Publishing.

Koçel, T., 2001. Business management. Istanbul: Beta Printing.

Kurban, C., 2015. Decision making styles of school administrators according to individual perceptions. Master Thesis. Pamukkale University Institute of Educational Sciences.

Kuzgun, Y., 1992. Decision strategies scale: Development and standardization. VII. National Psychology Congress Scientific Studies, Ankara. pp: S161-170.

Mağden, D. and A.A. Küçük, 1993. Investigation of the relationship between locus of control and self-esteem. 9. Seminar on Pre-school Education and Dissemination, Ankara.

Mann, L., M. Radford, P. Burnett, S. Ford, M. Bond, K. Leung, H. Nakamura, G. Vaughan and K.S. Yang, 1998. Cross-cultural differences in self-reported decision-making style and confidence. International Journal of Psychology, 33(5): 325-335.Available at: https://doi.org/10.1080/002075998400213.

Marco, C.D., P.J. Hartung, I. Newman and P. Parr, 2003. Validity of the decisional process inventory. Journal of Vocational Behavior, 63(1): 1-19.Available at: https://doi.org/10.1016/s0001-8791(02)00018-0.

Mau, W.C., 2000. Cultural differences in career decision-making styles and self efficacy. Journal of Vocational Behavior, 57(3): 365378.Available at: https://doi.org/10.1006/jvbe.1999.1745.

Ölçüm, D., 2015. The effect of school administrators 'decision making styles on teachers' job satisfaction. Master Thesis, Sakarya University, Institute of Educational Sciences.

Shiloh, S., S. Koren and D. Zakay, 2001. Individual differences in compensatory decision-making style and need for closure as correlates of subjective decision complexity and difficulty. Personality and Individual Differences, 30(4): 699-710.Available at: https://doi.org/10.1016/s0191-8869(00)00073-8. 
Temur, Ö.F., 2012. The effect of managers 'decision making styles on teachers' organizational commitment according to teacher perceptions. Master Thesis, Recep Tayyip Erdoğan University Institute of Social Sciences.

Tuinstra, J., F. Van Sonderen, J. Groothoff, W. Van Den Heuvel and D. Post, 2000. Reliability, validity and structure of the adolescent decision making questionnaire among adolescents in the Netherlands. Personality and Individual Differences, 28(2): $273-285$.

Üngüren, E., 2011. Personality characteristics, decision making styles and their reflections on organizational consequences on the axis of psychobiological personality theory. Doctor Thesis. Mediterranean Uiversiversi Institutes of Social Sciences. Antalya.

Vural, M., 2013. Investigation of the decision making and thinking styles of sports managers working in central and provincial organization of sports general directorate. Master Thesis. Selcuk University Institute of Health Sciences.

Vural, M., 2016. Investigation of organizational justice perceptions and decision making and organizational commitment of sports federation staff. Doctor Thesis. Sakarya Uiversiversi Institute of Educational Sciences. 